\title{
Performance Evaluation of Improved Oat Varieties/Accessions at East Guji Zone, Oromia, Ethiopia
}

\author{
Tamrat Dinkale ${ }^{1, *}$, Wubshet Tesfaye ${ }^{2}$, Yerosan Wekgari ${ }^{3}$ \\ ${ }^{1}$ Oromin Agricultural Research Institute, Mechara Agricultural Research Center, Mechara, Ethiopia \\ ${ }^{2}$ Oromin Agricultural Research Institute, Fedis Agricultural Research Center, Harar, Ethiopia \\ ${ }^{3}$ Oromin Agricultural Research Institute, Haro Sebu Agricultural Research Center, Haro Sebu, Ethiopia
}

Email address:

tamrat.dinkale@gmail.com (T. Dinkale)

${ }^{*}$ Corresponding author

\section{To cite this article:}

Tamrat Dinkale, Wubshet Tesfaye, Yerosan Wekgari. Performance Evaluation of Improved Oat Varieties/Accessions at East Guji Zone, Oromia, Ethiopia. Ecology and Evolutionary Biology. Vol. 5, No. 4, 2020, pp. 121-124. doi: 10.11648/j.eeb.20200504.11

Received: September 16, 2020; Accepted: September 29, 2020; Published: October 30, 2020

\begin{abstract}
The study was conducted with the objectives to introduce adaptive, high grain and forage yielder of improved Oat accessions/varieties for mid land of Guji zone, Oromia, Ethiopia. The experiment was conducted in Randomized Complete Block Design (RCBD) with three replications under Bore Agricultural Research Center, Adola sub site for two consecutive (2013/14 to 2014/15) in the mean season. Data of 50\% date flowering, date of mature, biomass yield, plant height and diseases incidence were collected. Significant $(\mathrm{P}<0.001)$ differences were observed for all measured agronomic traits except for lodging and green fodder yield. The result indicates that Jasari was the shortest and Grayaleris was the longest in terms of date of $50 \%$ flowering. Grayaleris Variety is late mature whereas Bona Bas variety is early mature. The maximum and minimum plant height was recorded from Lampton and Grayaleris variety respectively that showed significant $(\mathrm{P}<0.001)$ variation. Jasari variety $(90 \%)$ followed by $6710(83.33 \%)$ accession and lampton $(78.33 \%)$ variety was the most susceptible and has low resistance to disease reaction (leaf and stem rust) and the lowest diseases severity was recorded from Bona Bas (1.67\%) followed by Bonsa $(6.6 \%)$ and 79Ab382 (TX) 80SA95 (10\%) varieties. The maximum grain yield (28.85 quant/ha) was produced by accession 79Ab382 (TX) 80SA95 followed by accessions CI-8235 and CI-8237 which where (26.48 and 26.43 quant/ha) respectively and Lampton variety produced minimum grain yield (15.36 quant/ha). From this study, it is concluded that the oat varieties/ accessions 79Ab382 (TX) 80SA95, CI-8235 and Bonsa were found a promising in terms of grain yield, green fodder yield, absence of lodge and diseases resistance than others that could be demonstrated and popularized as an alternative feed resources under smallholder conditions in the study areas and other places of Guji zones of Oromia region with similar climatic and edaphic conditions.
\end{abstract}

Keywords: Accessions, Biomass Yield, Disease Reaction, Grain Yield and Variety

\section{Introduction}

Oat (Avena sativa L.) is an important multi-purpose cereal crops cultivated for grain, feed and straw over more than 9 million hectares globally [3]. Traditionally oats have been cultivated in cropping areas not appropriate for wheat, barley or maize and the cultivated area maintained stable over the years and it is adapted to wide range of soil types and because on marginal soils oats can perform better than other small-grain cereals [1]. It is also the most important winter cereal fodder crops [6] and liked by animals due to high palatability, quick growing succulent, softness and nutritious fodder crop. The improved varieties of oats produce threefold green fodder i.e. 60-80 tons per hectare and can feed double number of animals per unit area as against the traditional fodder crops [4]. The oats varieties have already been developed possessing characteristic i.e. early to late duration, high yielding, more nutritious, palatable, multi cut and disease free varieties for various agro-ecological zones. Oat is a cold and drought tolerant crop and it provide green fodder during the lean period when green fodder is scarce and animals are fed with dry fodder [5].

Selection of the promising oat varieties is one of the most 
important decisions of a plant breeder. This decision has an impact on the potential yield (forage and grain), seed quality (test weight and protein), disease and insect management and maturity of the crop. Introduction of the new oat cultivars along with the expansion of dairy has given impetus to commercial forage growing areas [13]. There is no any animal feed technology which is tested mid land agro ecology of Guji zone and no information on improved forage production due to the remoteness of the area and after established, Bore Agricultural Research Center is try to introduce improved forage production technologies. Therefore, the experiment was conducted with the objectives of introduce adaptive, high grain and forage yielder of improved Oat accessions/varieties to the area so as to address farmers in quality and quantity of forages for sustainable livestock production and productivity of their by contributing to the food security through increasing livestock production

\section{Materials and Methods}

\subsection{Description of the Study Area}

Adola Rede district is located $470 \mathrm{~km}$ away from Addis Ababa, the capital city of Ethiopia, to the South and $120 \mathrm{Km}$ from the zonal capital city, Negele Borena. The district is bordered by Ana Sora district in the North, Wadera district in the South and Odo Shakiso in the West and Girja district in the East directions. The district has altitude range of 13502340 m.a.s.l., total land coverage of $1254.56 \mathrm{~km}^{2}$, annual mean of $1000 \mathrm{~mm}$ rainfall and annual average of $28^{\circ} \mathrm{C}$ of temperature.

Adola district is practiced mixed farming, mining, forest product production and semi-nomadic economic were the major livelihood of farmers. The district is characterized by three agro- climatic zones, namely Dega $11 \%$ humid, Weina Dega $29 \%$, sub humid and Kola $60 \%$ dry arid respectively which are suitable for production of different crops. The rainfall pattern of the study area is bimodal for lowland and midland areas and uni-modal for highland parts. The major soils of the district are Nitosols (red basaltic soils) and Orthic Acrosols. They are red brown and black brown in colors and they are found on sloping terrain. Therefore, their agricultural utilization is good under natural vegetation. The major crop produced in the area includes maize, sorghum, teff, haricot bean, chat, coffee and the others.

\subsection{Experimental Materials, Treatments and Experimental Design}

The experiment was carried out from 2013/14 to 2014/15 for two years at Bore Agricultural Research Center (BOARC), Adola Rede research sub site of Guji, Oromia National State, Ethiopia. The study was conducted with randomized complete block design (RCBD) in three replications of plot size $3 \times 4 \mathrm{~m}^{2}$ of a total area of $12 \mathrm{~m}^{2}$. The space between block, plot and row were $1.5 \mathrm{~m}, 1 \mathrm{~m}$ and $0.25 \mathrm{~m}$ respectively. Land preparation was done from end May to the mid of September for three times with a tractor for the first, then the second and third by oxen and manually harrowed and leveled before planting. After land preparation was done, twelve Oat varieties/Accessions (Jasari, 6710, 712, CI-8237, CI-8235, 6207, Bonsa, 80SA95, 5453, Lampton, Bona Bas, Grayalegris) were sown under rain fed conditions. The seed rate of $80 \mathrm{~kg} \mathrm{ha}^{-1}$ was sown through hand drilling with $5-10$ $\mathrm{cm}$ deeps when the soil has enough moisture for seed germination. Fertilizer application was uniformly applied to all plots in the form of DAP and Urea at the rate of 50 and $100 \mathrm{~kg} / \mathrm{ha}$ respectively at the time of sowing. All other crop management practices were done uniformly to all plots as required.

\subsection{Data Collection and Measurement}

Data was collected for date of $50 \%$ flowering, date of maturity, lodging percentage, disease resistance, green forage yield, plant height and seed yield data were carefully collected for all accessions/varieties for two consecutive years.

\subsection{Statistical Analysis}

All agronomic data was analyzed by using the Fisher's analysis of variance (ANOVA) techniques and treatment's means were compared using Least Significance Difference (LSD) test at 5\% probability level [9].

\section{Result and Discussion}

\subsection{Agronomic Traits of Napier Grass Cultivars}

\subsubsection{Date of 50\% Flowering and Date of Maturity}

The data recorded for $50 \%$ flowering date showed that there was statistically significance $(\mathrm{P}<001)$ difference among the varieties/accessions. The shortest and longest date of $50 \%$ flowering was recorded from Jasari (58 days) and Grayaleris (74.67 days) respectively. This result is showed shorter days to $50 \%$ flowering as Nawaz et al [7] reported from 150.33 to 133.33 days of $50 \%$ flowering and [10] from 113.25 to 127.0 days. Days taken to $50 \%$ flowering in the varieties are different probably due to their varietal characteristics and adaptability.

The maximum and minimum date of maturity was recorded from Grayaleris (160 days) and Bona Bas (118.33 days) respectively. [7] reported that the maximum and minimum 210 and 179 days to mature respectively were longer than the present result. Significant differences in days taken to maturity among different varieties may be due the genetic makeup or adaptability.

\subsubsection{Plant Height and Green Fodder Yield}

Plant height is a major factor contributing towards forage yield of different crops. The data showed that there was significance $(\mathrm{p}<0.001)$ variation among varieties/ accessions (table 1). From present study, the minimum height of 93.33 $\mathrm{cm}$ was recorded from Grayaleris variety while the maximum height of $156 \mathrm{~cm}$ was recorded from Lampton variety which is in line with $[6,7]$ who reported variation in plant height 
among the varieties. $([11,10]$ reported that Lampton variety produce the tallest plant height $(179.25$ and $184.5 \mathrm{~cm})$ respectively which is a similar result with the present findings that stand first. The main cause of those differences in plant height is due to differences in genetic makeup of the varieties/accessions of oats. [12] Explained that plant height may differ in varieties due to environmental conditions which in turn cause variation in hormonal balance and cell division rate. The significant effect of variety on plant height in present study is in agreement with previous findings $[11,6,5]$.

\subsubsection{Green Fodder Yield}

Data regarding mean green forage yield (GFY) of oat varieties is presented in (Table 1). There was no statistically significance $\quad(\mathrm{P}>0.05) \quad$ difference among the varieties/accessions. Numerically the maximum green fodder yield 66.67 ton $/ \mathrm{h}$ was obtained from bonsa followed by bonabas $(65.33$ ton $/ \mathrm{h})$ and accession 712 (64.93 ton $/ \mathrm{h})$. Minimum fodder yield 36.93 ton $/ \mathrm{h}$ was recorded from Grayaleris. The result of present study is in contrast with [5] and [6] who reported that significance difference among the genotypes of oat. [6] Reported from 33.33 to 47.6t/ha and [5] from 45.8 to $53.9 \mathrm{t} /$ ha which is lower than the present results. Usman Semman et al [11] reported from 105.60 to $54.40 \mathrm{t} / \mathrm{ha}$ of green fodder yield which was higher than the present.

\subsubsection{Grain Yield}

There were significant $(\mathrm{P}>0.001)$ differences in the grain yield of oat varieties/accessions. It is evident from the data that maximum grain yield (28.85 quant/ha) was produced by accession 79Ab382 (TX) 80SA95 followed by accessions CI8235 and CI-8237 which produced grain yields (26.48 and 26.43 quant/ha) respectively. Lampton oat variety produced minimum grain yield (15.36 quant/ha) followed by variety Grayalegris (15.6 quant/ha) similar findings with [10] Lampton produce lower grain yield. This is might be due to lodging nature of Lampton variety. The grain yield obtained from the present finding was higher than yield reported by Nawaz et al [7] which was 8.10 to 24.03 quant/ha and almost similar with Dawit Abate and Mulusew Fikere [2] who reported from 21.70 to 29.80 quant/ha and Sanchez-Martin et al [8] reported oat could be produced 21.70 to 17.20 quant/ha that grain yield was strongly affected by agro-climatic conditions.

\subsubsection{Diseases Occurrence and Lodging Percentage}

The diseases severity was the most important criteria during the data collection. Statistical variation $(\mathrm{P}<0.001)$ was observed among the varieties/accessions tested. Jasari variety (90\%) followed by $6710(83.33 \%)$ accession and lampton $(78.33 \%)$ variety was the most susceptible and has low resistance to disease reaction (leaf and stem rust). The lowest diseases severity was recorded from Bona Bas (1.67\%) variety followed by Bonsa $(6.6 \%)$ and $79 \mathrm{Ab} 382$ (TX) 80SA95 (10\%). Even though, Bona Bas variety is a diseases tolerant, Bonsa and 79Ab382 (TX) 80SA95 genotypes are superior to Bona Bas in terms of grain yield. Disease is the most factor reduce grain yield [8] reported that the most affected by diseases (rust), the lowest in yield.

Table 1. Average performance of different oat varieties/accession under the agro-climatic conditions of Adola Rede district.

\begin{tabular}{|c|c|c|c|c|c|c|c|}
\hline Treatments & D50\%F & MD & Dis\% & Lodg \% & Plh & GFYt/h & GYldqtha \\
\hline 6710 & $64^{\text {cde }}$ & $120^{\mathrm{ef}}$ & $83.33^{\mathrm{ab}}$ & 8.33 & $154.67^{\mathrm{ab}}$ & 53.6 & $20.5^{c}$ \\
\hline 712 & $64.67^{\text {cde }}$ & $119^{\text {ef }}$ & $13.33^{\mathrm{efg}}$ & 0 & $136^{\mathrm{d}}$ & 64.93 & $21.89^{c}$ \\
\hline 5453 & $66^{\mathrm{cd}}$ & $121^{\mathrm{de}}$ & $11.67^{\mathrm{efgh}}$ & 0 & $138.33^{\mathrm{cd}}$ & 55.73 & $20.74^{\mathrm{c}}$ \\
\hline 6207 & $65^{\text {cde }}$ & $120.67^{\mathrm{de}}$ & $20 \mathrm{def}$ & 0 & $136^{\mathrm{d}}$ & 52.4 & $21.34^{\mathrm{c}}$ \\
\hline CI- 8237 & $63.67^{\mathrm{de}}$ & $122^{\mathrm{d}}$ & $21.67^{\mathrm{de}}$ & 0 & $150^{\mathrm{abc}}$ & 48.27 & $26.43^{\mathrm{ab}}$ \\
\hline CI-8235 & $64^{\text {cde }}$ & $124^{\mathrm{c}}$ & $25^{\mathrm{d}}$ & 0 & $148^{\mathrm{abcd}}$ & 58 & $26.48^{\mathrm{ab}}$ \\
\hline Bonsa & $66.67^{\mathrm{c}}$ & $120^{\mathrm{ef}}$ & $6.6^{\text {gh }}$ & 0 & $138^{\mathrm{cd}}$ & 66.67 & $25.4^{\mathrm{b}}$ \\
\hline Lampton & $70^{\mathrm{b}}$ & $128^{\mathrm{b}}$ & $78.33^{\mathrm{b}}$ & 10 & $156^{\mathrm{a}}$ & 46.93 & $15.39^{\mathrm{d}}$ \\
\hline BonaBas & $59.67^{\mathrm{f}}$ & $118.33^{\mathrm{g}}$ & $1.67^{\mathrm{h}}$ & 0 & $154.33^{\mathrm{ab}}$ & 65.33 & $17.01^{\mathrm{d}}$ \\
\hline Grayalegris & $74.67^{\mathrm{a}}$ & $160^{\mathrm{a}}$ & $38.33^{\mathrm{c}}$ & 0 & $93.33^{\mathrm{e}}$ & 36.93 & $15.6^{\mathrm{d}}$ \\
\hline Jasari & $58^{\mathrm{f}}$ & $121 d^{e}$ & $90^{\mathrm{a}}$ & 0 & $145.33^{\mathrm{abcd}}$ & 38.8 & $17.58^{\mathrm{d}}$ \\
\hline Mean & 64.94 & 128.83 & 33.33 & 1.52 & 140.97 & 53.89 & 21.44 \\
\hline $\mathrm{CV}$ & 2.69 & 0.67 & 17.85 & 386.05 & 5.62 & 21.53 & 7.6 \\
\hline P-Value & $* * *$ & $* * *$ & $* * *$ & NS & $* * *$ & NS & $* * *$ \\
\hline
\end{tabular}

a, b, c.. Means in a column within the same category having different superscripts differ (from $\mathrm{P}<0.05$ to $\mathrm{P}<0.001$ ); $*=$ significant, $* *=$ very significant, $=* * *$ highly significant, $\mathrm{D} 50 \% \mathrm{~F}=$ date of $50 \%$ flower, $\mathrm{MD}=$ maturity date, $\mathrm{DS},=$ disease severity, Lodg $=$ lodging, Plh $(\mathrm{cm})=$ plant height in centi meter, GFYt $/ \mathrm{h}=$ Green fodder yield tone per hectare, GYldqtha = grain yield quintal per hectare.

\section{Conclusion and Recommendation}

On the basis of two years field investigations, clearly indicate that oat varieties/ accessions 79Ab382 (TX) 80SA95, CI-8235 and Bonsa were performed more efficient with respect to grain yield, Green fodder yield, absence of lodge and resistance to diseases than other tested oat varieties/accessions. It is possible to conclude these varieties/accessions could be demonstrated and popularized as an alternative feed resources under smallholder conditions 
in the study areas and other places of Guji zones of Oromia region with similar climatic and edaphic conditions.

\section{Conflict of Interests}

The authors declare that they have no competing interests.

\section{Acknowledgements}

I would like to extend my sincere gratitude to Oromia Agriculture Research Institute (OARI), Bore Agricultural Research Center (BOARC) for the research grants and all Animal feed research staffs.

\section{References}

[1] Buerstmayr, H., Krenn, N., Stephan, U., Grausgruber, H., Zechner, E., 2007. Agro-nomic performance and quality of oat (Avena sativa L.) genotypes of worldwideorigin produced under central European growing conditions. Field Crops Res. $101,92-97$.

[2] Dawit Abate and Mulusew Fikere (2014). Performance of fodder oat (Avena sativa L.) genotypes for yield and yield attributes in the highland of bale. Journal of Biology, Agriculture and Healthcare, 7 (9): 29-33.

[3] FAO, 2011. http://faostat.fao.org.

[4] Hussain, A., Muhammad, D., Khan, S., \& Bhatti, M. B. (1993). Forage yield and quality potential of various cultivars of oats (Arena sativa L.). Pakistan Journal of Scientific and Industrial Research, 36, 258-260.

[5] Irfan, M., Ansar, M., Sher, A., Wasaya, A., \& Sattar, A. (2016). Improving forage yield and morphology of oat varieties through various row spacing and nitrogen application. JAPS: Journal of Animal \& Plant Sciences, 26 (6).
[6] Lodhi, M. Y., Marghazani, I. B., Hamayun, K., \& Marri, M. J. (2009). Comparative performance study of different oat varieties under agro-climatic conditions of Sibi. Journal of Animal \& Plant Sciences, 19 (1), 34-36.

[7] Nawaz, N., Razzaq, A., Ali, Z., Sarwar, G., \& Yousaf, M. (2004). Performance of different oat (Avena sativa L.) varieties under the agro-climatic conditions of BahawalpurPakistan. Int. J. Agric. Biol, 6 (4), 624-626.

[8] Sanchez-Martin, J., Rubiales, D., Flores, F., Emeran, A. A., Shtaya, M. J. Y., Sillero, J. C. \& Prats, E. (2014). Adaptation of oat (Avena sativa) cultivars to autumn sowings in Mediterranean environments. Field Crops Research, 156, 111122.

[9] Steel, R. G. D., J. H. Torrie, and D. A. Dickey (1997). Principles and procedures of statistics, a biological approach. 3rd Edition. McGraw Hill Book Co., Inc., NY, USA. pp. 352358 .

[10] Tamrat Dinkale and Usman Semman (2019). Demonstration and Popularization of Improved Oat Varieties/Accessions at the Highland of Guji Zone High Land, Ethiopia. Journal of Natural Sciences Research 9 (5): 33-37.

[11] Usman Semman, Bedasa Eba and Tamrat Dinkale (2018). Performance Evaluation of Improved Oat Varieties/Accessions at the Highland of Guji Zone, Bore, Ethiopia. Journal of Biology, Agriculture and Healthcare, 8 (17).

[12] Zaman, Q., Hussain, M. N., Aziz, A., \& Hayat, K. (2006). Performance of high yielding oat varieties under agroecological conditions of DI Khan. Journal of Agricultural Research, 44 (1), 29-35.

[13] Shah SAS, Akhtar LH, Minhas R, Bukhari MS, Ghani A, Anjum MH (2015). Evaluation of different oat (Avena sativa L.) varieties for forage yield and related characteristics. Sci Lett, 3 (1): 13-16. 